approach is exceedingly successful in producing a good, workable, initial description. With that kind of solid start, physical science can then safely proceed to elaborate more sophisticated theories.

How far these methods will be successful in the world of living things is not yet known. The successes to date are very impressive. One feature after another that previously seemed to fall in a special 'vital' category has usefully yielded to biochemical or biophysical attack. As yet only a beginning has been made. How far the logical quantitative method will succeed here, it would be rash to forecast, although the prospects seem extremely promising.

Small beginnings at extending the scientific method into the social sciences have been made. In so far as these fields can be dealt with in terms of measurable quantities, they seem to present closely intercoupled situations that can very seldom usefully be handled with two or three variables and often require very many-for example, W. Leontief's input-output analysis of the United States economy deals with some fifty variables and regrets that it does not handle more. Science has, as yet, no really good way of coping with these multivariable but non-statistical problems, although it is possible that ultra highspeed computers will inspire now sorts of mathematical procedures that will be successful in cases where the effects are too numerous to handle easily but not numerous enough or of suitable character to permit statistical treatment. If we try to avoid the many-variable aspect of the social sciences by using highly simplified models of few variables, then these models ure often too artificial and over-simplified to be useful. The statistical approach, on the other hand, has recently exhibited-for example, in the stochastic models for learning-new potentialities in the field of human behaviour.

It is not at all necessary that the particular analytical techniques of the physical sciences be forced upon biological or social problems with the arrogant assumption that they can and should make unnecessary other types of insight and experience. During the Second World War, an extremely useful collaboration was developed, known often as operations analysis, in which reasoning of a mathematical type was applied to certain aspects of very complicated situations, but with no expectation that judgment, experience, intuition, or a vague sort of general wisdom would be displaced or superseded-rather only that these would be aided by whatever partial light could be furnished by quantitative analysis.

An important characteristic of science is its incapacity to be impractical. The most far-reaching discoveries and the most widespread useful applications flow regularly out of ideas that initially seem abstract and even esoteric.

Science presents the kind of challenge that attracts to it young men and women who tend to have a rather high degree of a certain kind of intelligence. But scientists are not special creatures : they are people. The great majority of scientists have the same distribution of moral and intellectual characteristics as other educated people.

If scientists are human, so also is science itself. For example, science does not deserve the reputation it has so widely gained of being based on absolute fact, of being wholly objective, of being infinitely precise, of being unchangeably permanent, of being philosophically inescapable and unchallengeable. There seem still to be persons who think that science deals with certainty; it deals with probabilities.
The ablest scientists themselves realize the postulational and provisional character of science. Perhaps not so widely recognized or accepted is the extent to which the development of Western science has been influenced by the general nature of Græco-Judaic culture, including especially the standards, arising within that tradition, of what is interesting and important.

The previous comments concerning general characteristics of science suggest that science is a very human enterprise, coloured by general ideas, changeable as any human activity must be, various in its possible forms, and a common part of the lives of all men.

Even the impressive methods that science has developed involve only improvement of procedures of observation and analysis that the human race has always used.

These comments do not support the concept of science as some sort of super creed. This point of view does not justify the notion that science is so special as to be unique, as well as so curious as to be incomprehensible. This does not depict scientists as strange creatures who are in one sense so objective, judicial and precise as to be incredible, and in another sense so apart from life as to be selfish and sinister. This does not set up quantitative analytical Western science as the only valid way in which man may approach and interpret experience.

These descriptive comments picture science as the servant of man, not his master ; and as a friendly companion of art and of moral philosophy.

The lack of general comprehension of science is dangerous both to science and to the public, these being interlocked aspects of the common danger that scientists will not be given the freedom, the understanding and the support that are necessary for vigorous and imaginative development.

\section{TECHNICAL INFORMATION SERVICES IN EUROPE}

$\mathrm{U}$

NDER the title "Technical Information Services in Europe", the European Productivity Agency of the Organization for European Economic Cooperation has published a report on the second meeting of technical information officers, held in Frankfurt-am-Main during May 2-6 last (from the Organization, 2 Rue André Pascal, Paris, 16e). The conference, which included delegates from twelve different countries, was intended to give participants an insight into the functioning of the technical information services which are an integral part of the German Productivity Centre at the Rationalisierungskuratorium der Deutschen Wirkschaft in Frankfurt, and the first section of the report outlines the services, activities and relations of this body. It is a private organization which has as its aim the rationalization of the entire German economy and increased productivity, and in this task representa. tives of science and engineering, of industry, and of trade, commerce and crafts, of trade unions and of government agencies are co-operating with it. It is organized both on a regional and on a subject basis and has a priority programme covering those fields where it is believed that an actual increase in productivity can be achieved. In referring to information services, Dr. Magnus, of the board of directors of the Rationalisierungskuratorium, emphasized the im- 
portance of bringing the inquirer to formulate his question correctly. Besides describing the activities of the information service, which up to April 1955 had answered more than ten thousand questions, this section of the report gives a brief account of information and documentation in Germany, including the work of the German Society for Documentation, the Association of German Engineers, and the Association of German Mechanical Engineering Firms and the Prior Art Information Service, Treuhandstelle Reichspatantamp, Berlin, and also of the operation in Germany of the Documents Exchange Scheme of the Organization for European Economic Co-operation.

The second section of the report deals with the activities and projects of the European Productivity Agency in the field of technical information, including Dr. A. King's address on the general policy of the Agency, which emphasizes that, to be efficient, the Agency must concentrate on work that is better done on an international basis than nationally. Much of the Agency's work next year will be devoted to encouraging relations between the various national productivity centres and to services which may be of use to them all. Dr. King also emphasized the importance of forward thinking on productivity matters and of providing a forum for the discussion of particular topies which may be only germinating in the minds of men in individual countries, so that understanding can be reached which will lead to international attack on a problem and accelerated action. In this connexion he said that the Agency had appointed a working party to consider automation and particularly its human relations and economic problems and the relation of the whole subject to the future industrial pattern of European countries. The Agency has also been considering the economic switch-over which the introduction of automation will entail. Dr. King thought that in the past tech. nical information work was too narrowly conceived and that its main task is to serve industry with the object of increasing productivity levels. He urged a closer relation between management and human relations and labour, on one hand, and the technological and technical information activities, on the other, and that at present not enough technical information of the less technological type is disseminated. Much new work is required of a research, survey and experimental nature in connexion with the social problems of technical innovation.

Suggestions made at the conference for future activities included the recommendation that the work of national technical information centres be undertaken for the general needs and within the scope of the overall productivity programme of the countries and productivity groups, and that the European Productivity Agency should intensify its relations with international vertical organizations and other international organizations in the field of technical information. The Agency was also asked to consider extending its system, in co-operation with the national technical information services, to include problems on management, human relations and similar topics. It was agreed that national technical information services should be encouraged to adopt the field officer method of providing technical information and that, while the Documents Exchange Scheme should not be regarded as a substitute for personal, organizational or multilateral contacts, which the national centres should encourage, it should include as much unpublished material as possible; in general, such centres should help each other with material which it is difficult to obtain. The conference suggested that those countries in which 'technical information days' have not yet been organized should make use of this idea, and that the European Productivity Agency and national centres should use every kind of publicity and publication to spread knowledge about technical information services.

\section{COMMONWEALTH FUND, NEW YORK}

\section{ANNUAL REPORT FOR 1954-55}

$\mathrm{T}$ HE thirty-seventh annual report of the Commonwealth Fund, New York, covering the year ended June 30, 1955*, records that forty-one Fellows were appointed to hold fellowships in the United States during 1955-56, and another sixteen will be in residence on second-year extensions, bringing the total of Fellows elected since 1925 to 729 . This figure includes 550 scholars appointed on applications through universities in Great Britain, and 139 Civil servants, of whom forty-two were from the Home Civil Service and ninety-seven from the Dominion and Colonial Services. It also includes thirty-three scholars from Western Europe in a programme of Continental fellowships which was started in 1952. Of the total appropriation of $3,469,972$ dollars during the year, 1,954,071 dollars was in the field of medical education, including research in educational environment and procedures and the evaluation of educational experiments, while a further 210,000 dollars was appropriated for advanced medical fellowships, and 206,650 dollars for advanced nursing education, including twenty-one new and five extended awards as well as block grants to five institutions. Appropriations of 887,926 dollars for medical research were voted for nine projects, four of which were for studies of organism-environment interaction, two for studies of integrative processes within the organism and three for studies in basic biology. Ten other projects have continued to receive support from appropriations voted in previous years. Grants for experimental health services totalled 137,750 dollars, including a renewed grant of $\mathbf{1 1 8 , 2 5 0}$ dollars to the Hunterdon Medical Centre, New Jersey, to underwrite, for the next three years, two-thirds of the cost of the Centre's community mental-health programme and 19,500 dollars to the Tennessee Medical Foundation for operating costs during the next two months. The Fund's publication programme continues to provide, in conjunction with the Harvard University Press, for the publication of manuscripts and books emanating from projects supported by the Fund in the field of health.

The appropriations for medical oducation went to twenty-seven institutions, six appropriations being grants for new projects and ten being extensions of assistance to old ones, while fifteen institutions received assistance from previous appropriations. Four of the new projects reflect the increased collaboration between medicine and social science. A three-year grant to Yale University was for an experimental graduate training programme in the social aspects of medicine, in which the experience

* Commonwealth Fund. Thirty-seventh Annual Report for the Year ending June 30,1955 . Pp. vii +46 . (New York : Commonwealth Fund, 1955.) 